\title{
EVALUASI PENDEKATAN PARTISIPATORI DALAM SENI, STUDI MURAL KOMUNITAS DI KAMPUNG KOTA
}

\author{
Ernest Irwandi 1), Setiawan Sabana ${ }^{2}$, dan Andryanto Rikrik Kusmara ${ }^{3)}$ \\ 1 ernest.irw@gmail.com \\ Institut Teknologi Bandung \\ 2 setiawansabana@yahoo.com \\ Institut Teknologi Bandung \\ 3 twinrik@gmail.com \\ Institut Teknologi Bandung
}

\begin{abstract}
Mural art does not only function as decoration but it is an art activity that impact social life. Decorating villages with murals has become an art movement across Java. Creation of mural in these villages involves many stakeholders (government, universities, students, artists), which can be considered as participatory art, that emphasize on collaboration and shared experiences. In participatory art, artists' and facilitator role is to encourage community creativity. This research focuses on art community murals using participatory action research approach. This research aim to analyze collaborative art creation models, and examine how art can empower a community.
\end{abstract}

Keywords: participatory, community murals, collaboration, empowerment.

\section{PENDAHULUAN}

Menghias kampung dengan mural telah menjadi gerakan seni khususnya di pulau Jawa, dan sebagian kampung telah menjadi kawasan wisata. Melalui penelusuran berita, pustaka dan wawancara kepada beberapa nara sumber, setidaknya ada 25 lokasi kampung di Pulau Jawa yang dihiasi dengan mural seperti pada tabel di bawah ini, walapun data ini masih terus berkembang seiring dengan waktu.

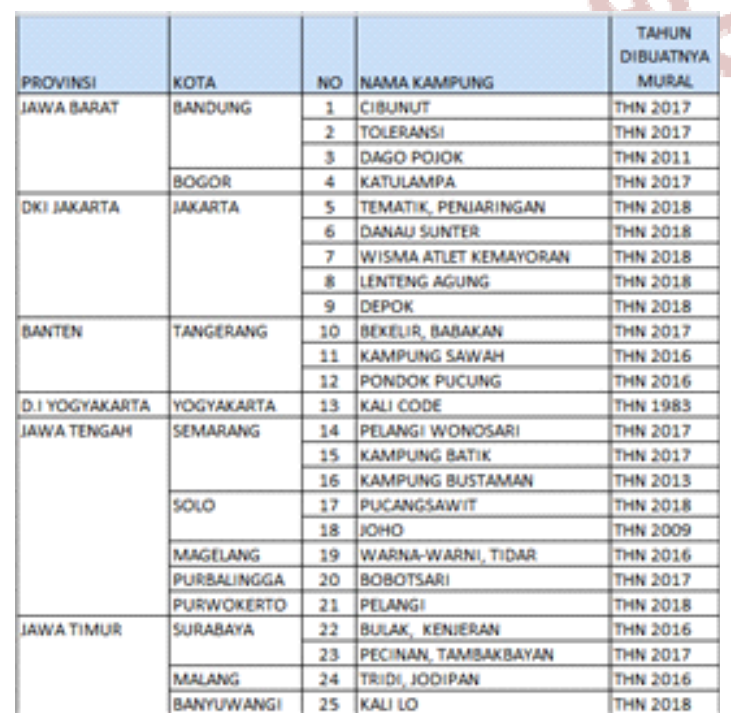

Gambar 1. Daftar nama Kampung Kota di Pulau Jawa yang dihiasi dengan mural

(Sumber: Irwandi, 2019)
Melihat fenomena seni mural yang berkembang belakang ini khususnya di kampung kota di Pulau Jawa, menunjukkan pastisipasi masyarakat untuk mempertahan-kan eksitensi tempat tinggalnya. Tembok-tembok telah diubah oleh warga menjadi vista ekspresi dan kampung menjadi ruang kreativitas bersama.

Kegiatan pembuatan karya mural berbasis komunitas telah banyak dilakukan dengan modelmodel kreativitas yang sangat beragam. Sebagai salah satu contoh adalah kegiatan yang pernah dialami oleh penulis, ketika pada tahun 2016 penulis dan kelompok mahasiswa program studi Desain Komunikasi Visual bersama dengan warga mengerjakan karya mural di Kampung Pondok Pucung, RT/RW 05 \& 06/02, Tangerang Selatan. Kegiatan awalnya dilakukan untuk perapihan lingkungan sebagai bentuk pengabdian kepada masyarakat. Berdasarkan observasi lapangan dan informasi dari wawancara kepada Bapak Syarifudin selaku Ketua RW02, ditemukan bahwa kondisi Kampung Pondok Pucung semakin hari semakin sempit seiring dengan bertambahnya penduduk, karena mulai berkurangnya lahan kosong tempat anakanak bermain, alhasil anak-anak mulai mengisi waktu luang mereka dengan cara-cara yang lain. Salah satu yang menjadi kebiasaan negatif adalah vandalisme terlihat dari tembok-tembok sekitar Pondok Pucung yang banyak dicoret-coret. 


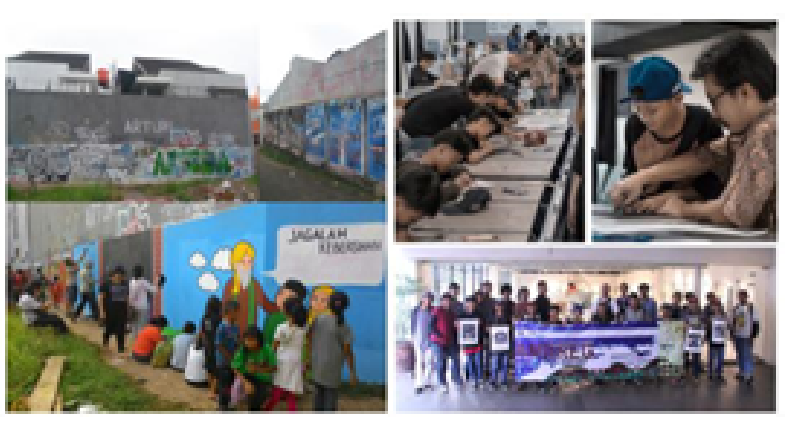

Gambar 2. Kiri atas- foto kondisi awal Kampung Pondok Pucung; kiri bawah- foto pembuatan mural di Kampung Pondok Pucung 2016; Tengah atas dan kanan atas- foto pelatihan seni; kanan bawah-foto Komunitas Pemuda Pondok Pucung dalam acara Ambreg 2017.

(Sumber: Ernest Irwandi)

Dalam rangka perbaikan lingkungan, pembuatan mural dipilih menjadi salah satu kegiatan pengabdian kepada masyarakat. Kolaborasi menjadi dasar dalam proses pembuatan mural, dengan mengutamakan keterlibatan warga dalam menentukan gagasan hingga proses pembuatan mural. Tema-tema yang diangkat adalah pesan-pesan positif yang ditujukkan kepada warga generasi muda. Kata-kata yang ditulis serta figur yang dilukis merupakan saran dari Ketua RW Bapak Syarifuddin. Kegiatan ini mengundang perhatian warga dan komunitas dari luar kampung Pondok Pucung sehingga berjalan dengan sangat semarak dan ramai pengunjung. Sebagai kelanjutan kegiatan pengabdian kepada masyarakat, pada tahun 2017 dilakukan juga pelatihan dan edukasi seni kepada pemuda Pondok Pucung. Rangkaian kegiatan yang panjang akhirnya berdampak pada terbentuknya komunitas Pemuda Pondok Pucung dengan ditandai dengan acara 'Ambreg'. Kegiatan pembuatan mural berbasis komunitas ini adalah titik awal penelitian tentang seni mural komunitas dengan pendekatan partisipatori, yang sedang dilakukan oleh penulis.

\section{KAJIAN LITERATUR}

Aktivitas seni rupa kontemporer yang diciptakan melalui proses partisipatif telah banyak menarik perhatian publik. Salah satu gerakan seni partisipatif adalah gerakan mural komunitas. Seni mural berbasis komunitas telah bergerak menuju model-model praktik seni di luar studio, keistimewaan seni mural komunitas tidak hanya pada objek seni, tetapi juga pada ruang yang merupakan situs produksi dan terjadi proses interaksi dan dialog (Barnett, 1984). Seni rupa partisipatif adalah sebuah pendekatan karya seni yang melibatkan partisipasi masyarakat ke dalam proses kreasi, di mana partisipan berperan sebagai penulis, editor sekaligus pengamat. Proses penciptaan karya seni partisipatif menitik-beratkan pada beberapa kata kunci antara lain: tingkat keterlibatan, kolaboratif, komunal, fasilitator dan melibatkan berbagai pemangku kepentingan (Kelly, 2014. Konteks dan konten seni dalam pendekatan seni partisipatoris, cenderung spesifik pada suatu permasalahan di suatu lokasi atau kondisi. Diskursus dalam ranah seni yang terkait dengan seni partisipatif, antara lain: seni relasional, seni kolaborasi, dimensi dialogis dalam seni, seni ruang publik dan seni berbasis komunitas. Pendekatan seni partisipatif juga menuai kritik terutama ketika seniman atau kelompok seni masuk ke dalam komunitas dengan ide-ide personal, maka di dalam proses kreasi seni partisipatif, sangat diperlukan keterbukaan terhadap ide-ide yang berkembang.

Proses kreasi seni partisipatif adalah pergeseran dari model produksi yang berangkat dari wilayah subjektif seniman ke model partisipatif di mana pengalaman bersama dalam berkarya merupakan hal yang paling penting. Pendekatan 'Seni Partisipatif' dan pendekatan 'Desain Partisipatif' seringkali menggunakan faktor-faktor kunci yang serupa. Pendekatan 'Desain Partisipatif' atau sering dikenal dengan istilah desain kolaboratif dan desain berbasis pengguna (user generated design) berpusat pada hubungan antara desainer dengan pengguna. Walaupun ada kemiripan di dalam wilayah interpretasi, antara relasi seniman dengan penglihat atau relasi antara desainer dengan pengguna, wilayah seni meletakkan aspek interpretasi pemirsa secara lebih longgar sedangkan wilayah desain memerlukan pertimbangan yang lebih ketat terutama pada aspek kenyamanan dan ergonomi.

Di dalam proses desain tradisional, peneliti bertindak sebagai penerjemah antara pengguna dan perancang, sedangkan dalam desain kolaboratifpartisipatif, seringkali mengharuskan peneliti untuk mengganti berbagai peran di dalam tahap-tahap penelitiannya, di dalam kondisi tertentu peneliti berperan sebagai pemimpin, pembimbing, pengamat dan fasilitator.

Dalam penggunaan pendekatan partisipatori, tangga Arnstein masih menjadi sebuah panduan awal bagi peneliti, terutama untuk mengetahui kondisi nyata berada di dalam tingkatan tertentu (Arnstein, 1969). Arnstein menggunakan analogi tangga untuk menjelaskan tahapan antara lain: 


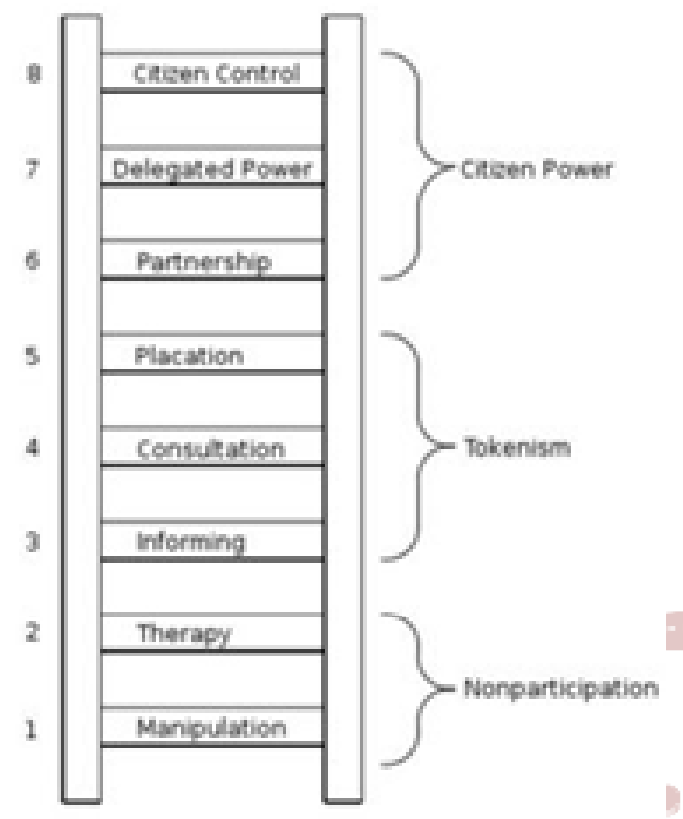

Gambar 3. Tangga partisipatori Arnstein 1969

(Sumber: Kindon, Pain dan Kesby 2007)

a) Pertama Manipulation dan kedua Therapy / Education

Pada anak tangga pertama dan kedua, Arnstein menjelaskan bahwa pada tahap ini partisipasi berada dalam posisi terendah, ketika pemegang kekuasaan atau fasilitator mendidik untuk mengubah sikap warga dalam rangka mendapatkan dukungan publik demi kesuksesan pemegang kekuasaan.

b) Informing

Pada anak tangga ketiga, tingkat partisipasi semakin meningkat walaupun masih rendah. Pada tahap ini fasilitator memberikan informasi satu arah. Informasi disampaikan kepada warga tetapi warga tidak diberikan peluang untuk berkontribusi terhadap keputusan-keputusan.

c) Consultation

Pada anak tangga keempat, pemegang kekuasaan atau fasilitator memberikan saran atau arahan kepada warga. Warga diberikan peluang untuk memberikan pandangannya. Walaupun pandangan warga didengar dan diperoleh melalui berbagai cara, warga tidak terlibat dalam pengambilan keputusan.

d) Placation

Pada anak tangga kelima adalah penempatan warga ke dalam sebuah forum. Warga diberikan kesempatan untuk berperan aktif sebagai pembentuk opini dan gagasan tetapi keputusan akhir tetap ada pada fasilitator atau pemegang kekuasaan. e) Partnership

Pada anak tangga keenam adalah kemitraan. Pada tingkat ini adanya negosiasi dan keterlibatan warga dalam pengambilan keputusan. Komunikasi dua arah antara pemegang kekuasaan dengan warga.

f) Delegated power

Pada anak tangga ketujuh Kekuasaan didelegasikan kepada warga untuk membuat keputusan. Fasilitator menetapkan keputusan bersama dan warga memiliki wewenang untuk memastikan akuntabilitas.

g) Citizen Control

Pada anak tangga kedelapan Warga memiliki kendali penuh dalam menangani seluruh perencanaan, membuat kebijakan, dan mengelola program.

Berdasarkan konsep tangga Arnstein, tingkat partisipasi tampak cukup jelas terutama dalam menggambarkan bagaimana posisi pemangku kepentingan, pemegang kekuasaan dan warga terutama dalam membuat atau menyesuaikan solusi. Tangga Arnstein juga dapat dipahami sebagai suatu proses penuntunan atau pemberdayaan ke tingkat akhir yaitu citizen control di mana warga memiliki kendali penuh atas gagasan dan implementasinya. Tantangan dari pendekatan partisipatori adalah bagaimana menyatukan berbagai hal. Penerapan pendekatan partisipatori dalam ranah seni dan desain memberikan tantangan baru karena seniman atau desainer tidak bekerja seorang diri atau dalam kelompok dengan aliran yang sama, maka sangat memungkinkan untuk terjadi gagasan-gagasan yang saling bertentangan. Walaupun demikian tantangan yang menarik di dalam proses ini adalah, bagaimana fasilitator dapat menyatukan berbagai hal untuk membuka kemungkinan baru. Konsep tangga Arnstein memudahkan pengertian mengenai tingkat partisipasi warga, namun konsep batas antara anak tangga yang dipaparkan oleh Arnstein menuai pertanyaan lebih lanjut. Selain batasan setiap anak tangga, model tangga Arnstein seringkali diandaikan sebagai proses yang bergerak secara linear, padahal dalam kenyataan seringkali proses bertumpang tindih di antara dua tingkatan atau lebih. Dalam perkembangannya pendekatan partisiatori sering digabungkan dengan penelitian tindakan atau Action Research. Menurut Kemmis dan McTaggart (1988), proses analisis dalam model partisipatif adalah suatu praktik dialektis, reflektif mengenai transformasi sosial. 


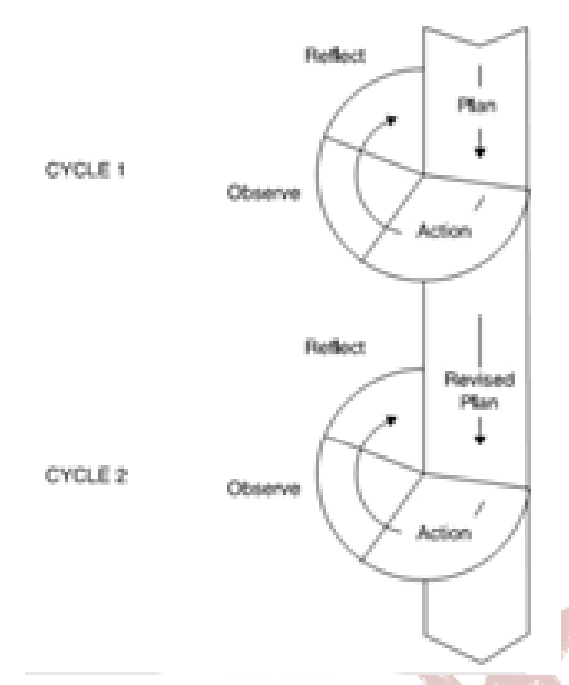

Gambar 4. Model Action Research Kemmis dan McTaggart 1988 (Sumber: Burns, 2010)

Menurut McTaggart, Participatory Action Research (PAR) dikembangkan sebagai sarana untuk meningkatkan dan menginformasikan praktik sosial, ekonomi, dan budaya. PAR pada prinsipnya adalah sekelompok kegiatan di mana individu dengan kekuatan, status tertentu yang memiliki pengaruh yang berbeda, berkolaborasi ke dalam suatu konteks masalah (McTaggart, 1991).

\section{METODE PENELITIAN}

Penelitian ini berusaha untuk menggali, mengkaji dan memperoleh gambaran tentang fungsi mural pada perubahan perilaku masyarakat di Kampung Pelangi dan dengan melakukan analisis terhadap beberapa faktor kunci seperti kearifan lokal, kekuatan sosial yang ada dan model kreasi seni kolaboratif. Penelitian ini bersifat kualitatif dengan pendekatan campuran.

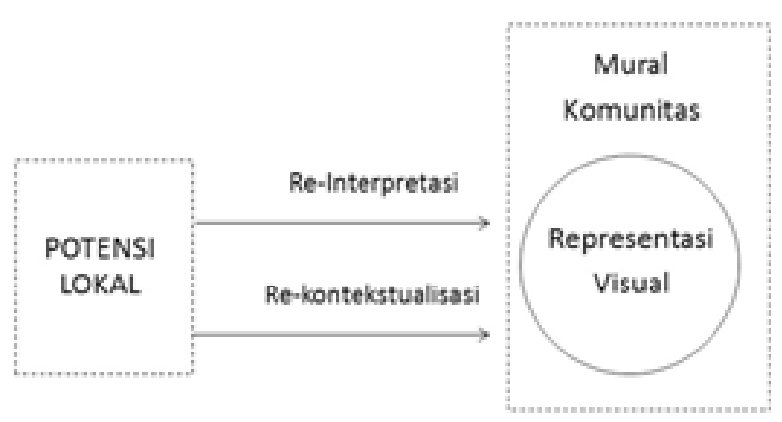

Gambar 5. Proses pembentukan gagasan untuk visualisasi mural (Sumber: Irwandi, 2019)
Tahap awal penelitian berupaya untuk memahami nilai-nilai lokal dan potensi lokal sebagai landasan gagasan visual untuk mural. Penelitian menggunakan pendekatan partisi-patori dalam proses pembuatan mural.

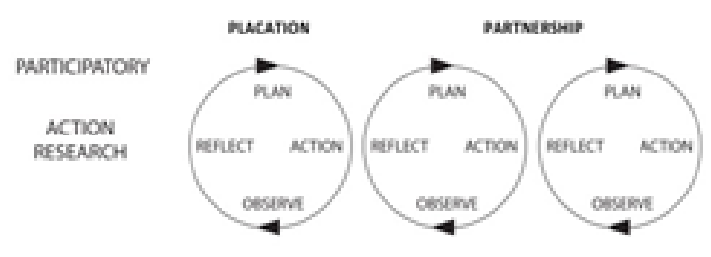

Gambar 6. Gagasan tentang model PAR yang akan digunakan dalam pendekatan penelitian bagian. Berdasarkan model PAR Anrstein, Kemmis dan McTaggart (Sumber: Irwandi, 2019)

Pendekatan partisipatori digunakan dalam penelitian ini guna menggali potensi kreatif, menghubungkan komunitas-komunitas serta memahami model-model kreasi seni kolaboratif yang dapat diterapkan.

\section{HASIL DAN PEMBAHASAN}

Penelitian dilakukan pada akhir tahun 2018 di Kampung Wonosari Kecamatan Randusari Semarang, atau saat ini dikenal sebagai Kampung Pelangi. Kampung Pelangi termasuk dalam program Kampung Tematik yang merupakan salah satu upaya Pemerintah Kota Semarang untuk meningkatkan kualitas lingkungan dengan memperhatikan faktor seperti: perbaikan kondisi lingkungan, penghijauan, mengangkat potensi sosial dan ekonomi melalui program pemberdayaan, mening-katkan karakter budaya atau kearifan lokal, dan meningkatkan ciri khas setempat yang lebih kuat sehingga menjadi ikon wilayah. Walaupun warna-warni Kampung Pelangi telah berhasil menjadi identitas baru Kota Semarang, masih diperlukan upaya-upaya kreatif lainnya untuk memperkaya nilai terutama mengenai eksplorasi terhadap budaya lokal dan konteks sejarahnya. Penelitian ini dilakukan demi menjawab: bagaimana proses kreasi mural dapat menciptakan suatu keberlanjutan bagi daya kreatif di Kampung Pelangi?

Penggunaan pendekatan Partisi-patory Action Research (PAR) dalam penelitian ini, diharapkan dapat membuka wawasan peneliti khususnya mengenai model-model kreasi seni yang dapat diterapkan dalam tahap-tahap mengelola gagasan, menggali kemungkinan-kemungkinan kreativitas di dalam suatu komunitas dan model-model pemberda-yaan suatu 
komunitas dalam masyarakat khususnya dalam konteks kreativitas.

Penelitian ini masih dalam tahap awal yaitu tahap rancangan penelitian dan penelususran data awal. Hipotesis dibatasi pada dua tingkatan menurut tangga Arnstein, yaitu tingkat Placation dan Partnership (Kindon, Pain, and Kesby, 2007). Hipotesis dibangun berdasarkan pengalaman penulis ketika melakukan kegiatan mural di Kampung Pondok Pucung di tahun 2016. Pada tingkat Placation ketika warga dilibatkan ke dalam suatu kelompok kreatif dan kelompok diskusi, warga diberikan kesempatan untuk berperan aktif dalam mewujudkan gagasan, walaupun pertimbangan akhir dalam tetap pada fasilitator. Pada tahap ini eratnya relasi peneliti dengan warga merupakan faktor kunci yang dapat menghasilkan keberhasilan atau warga mulai meningkatkan derajat partisipasinya. Ketika warga telah merasakan pengalaman diskusi dan gagasannya telah diwujudkan ke dalam karya akhir, ada rasa kepemilikan terhadap visual mural sehingga ketika kegiatan serupa diulang kembali, tumbuh keinginan untuk terlibat lebih lanjut.

Pada tingkat selanjutnya atau pada anak tangga keenam 'partnership', komunikasi dua arah dengan warga lebih banyak dilakukan. Suasana diskusi dalam tahap perencanaan dan keterlibatan warga dalam pengambilan keputusan mulai ditingkatkan. Hipotesis ini akan melandasi pola penelitian selanjutnya di Kampung Pelangi Semarang, terutama untuk mengetahui bagaimana keperansertaan warga untuk ikut membuat keputusan dan bagaimana mengevaluasi hasil pelaksanaan pada setiap tahap PAR.

\section{KESIMPULAN}

Pendekatan PAR dalam penelitian terhadap pembuatan karya seni berbasis komunitas, akan menunjukkan tingkat partisipasi warga dan pemberdayaan dapat ditingkatkan ketika ditemukan indikator-indikator yang memadai. Selain itu pendekatan PAR juga dapat menunjukkan multi peran bagi seniman dan fasilitator. Hipotesis penelitian ini mencoba membuktikan bahwa seniman bukan hanya sebagai penggagas visual tetapi sebagai katalisator yang dapat memantik kreativitas warga di suatu komunitas.

\section{DAFTAR PUSTAKA}

Arnstein, Sherry R.(1969) 'A Ladder Of Citizen Participation', Journal of the American Planning Association, 35: 4, 216 - 224.

Barnett, A.W. (1984): Community Murals: The People's Art. Cranbury, NJ: Associated University Press, Inc.

Burns, A. (2010). Doing action research in English language teaching: A guide for practitioners. New York: Routledge.

Kelly, M. (2014). Encyclopedia of Aesthetics, London: Oxford.

Kemmis, S dan McTaggart, R. (1988). The action research planner (3rd ed.). Geelong, Australia: Deakin University Press.

Kindon, S., Pain, R. and Kesby, M (2007). Participatory Action Research Approaches and Methods: Connecting people, participation and place. London: Routledge

Knight, C. K. and Senie, H. F. (2016): A Companion to Public Art, Wiley Blackwell.

Leavy, P. (2017). Research Design Quantitative, Qualitative, Mixed Methods, Arts Based, and Community Based Participatory Research Approaches. London: Guilford Press.

McTaggart, R. (1991). Action research: A short modern history. Geelong, Australia: Deakin University Press.

Tunnacliffe, C.M. (2016): The Power of Urban Street in Re-Naturing Urban Imaginations and Experiences, London, The Bartllet, London, University College London. 